\section{Polarization of Attitudes}

Despite all the alarums and excursions of recent months most doctors take little active interest in medical politics and have neither the time nor the inclination to master the intricacies of official reports, proposals, or counterproposals or to attend meetings. Morale within this silent majority has never been lower, however-as is shown by the first of a new series of Conversations with Consultants at p. 675. Perhaps the most disturbing change in the last few weeks has been the evidence that after more than 25 years of effective unity the medical services in Britian could be moving into two distinct and separate sectors.

Consultants at Moorfield's Eye Hospital have made arrangements $^{1}$ to treat their private patients in a modern, wholly private hospital in another part of London-a decision forced upon them by trade union action at Moorfields that had made it impossible for private patients to be treated there. Throughout the country, indeed, part-time consultants are finding that hospital administrators will apparently do nothing to oppose union action against private patients. When the first threats of this kind were made at the Charing Cross Hospital last summer ${ }^{2}$-well before there was any question of consultants working to contract-the Department of Health did nothing effective to restrain the union concerned, and the Secretary of State's repeated talk ${ }^{3}$ of the Government's commitment to phase out private practice gave it tacit approval. Just possibly a negotiated, planned phasing out of private practice from N.H.S. hospitals could have been achieved without causing any permanent damage to the Service. The present situationparallelled by Mr. Prentice's decision to phase out direct grant schools by 1976-will ensure hardening of attitudes as the profession is hurried and hassled into making the best arrangements it can at short notice.

For private practice will continue; and for the many doctors who believe in the concept of the N.H.S. the tragedy is that the polarization of attitudes achieved by the Government is likely to encourage the growth of private practice rather than its decline. Ten years or so ago private practice seemed to be on its way out in Britain, as the hospital building programme got into its stride and there was within the hospital service a general feeling that standards were rising. This was the time when enthusiastic consultants worked long hours, doing extra lists, using five-day wards and outpatient surgery, and succeeded in many hospitals in eliminating waiting lists. In such an atmosphere private practice remained what it ought to be: an expensive luxury for those for whom time is money or for whom individual attention is worth the cost.

What is happening now, however, is that the underfinancing of the Health Service has become so serious that it is interfering with the "job satisfaction" that sustains morale within a profession. Hospital building has virtually stopped; the quality of nursing care and the auxiliary services has dropped precipitously; industrial disputes-once unknown in hospitals-have become commonplace. Consultant staff, worried by the decline in standards, first became restless when they were left behind after general practitioners and then junior staff had received pay rises and recognition that work outside normal hours warranted extra payment. However, any progress that might have been made last year in negotiating a new contract for consultants was stymied when the atmosphere was soured by the sudden eruption of union action against private beds. This factor, really irrelevant to the discussions, was added to the remit of the Owen Working Party at the insistence of the present Government.
While the working party degenerated into acrimonious factions, the descent of the N.H.S. into anarchy has accelerated. Each week there are fresh press reports of withdrawals of labour, of union officials deciding who may or may not be admitted to hospital - and of the rapid expansion of facilities by the private sector. An Independent Hospital Group has now been formed to provide facilities throughout the country for private practice. ${ }^{4}$ We are close to the point of no return. Once a comprehensive service of private hospitals, nursing homes, and similar units has been established, a two-tier system will be with us in perpetuity.

One outstanding achievement of the N.H.S. in its first 25 years was that it had made private practice an expensive anachronism (outside London). The essence of the part-time contracts agreed in 1955 and 1961 was that they were "gentlemen's agreements." Maximum part-time consultants agreed to devote a substantial part of their time to the N.H.S. in return for the freedom to see and treat private patients as and when convenient. The system was open to abuse and it has been abused by a few consultants; but is that abuse any worse than academic globe-trotting by a professor or the attitude of the senior lecturer who spends all his time in the laboratory and never teaches? Only as the calls on the time of the average consultant have grown in recent years (partly because junior staff have been working fewer hours) has the compromise become more difficult to work. Nevertheless, compromise has been possible, but in most parts of the country it has depended on there being facilities for private practice within the N.H.S. hospital. In these cases consultants have been able to be geographically whole-time; and, more important, consultants have been able to treat occasional private patients without interfering with their N.H.S. commitments.

The concept of treating private patients in this informal way seems to be doomed by current Government attitudes. These seem designed to make independent practice-and private patients are not the only form of independent practicefinancially worthwhile only if the consultant concerned does a lot of it. Surely this will prove a tragic error. Forced into making that decision, consultants in surgery, gynaecology, and other specialties with high earning potential in the private sector, will opt for a part-time contract-with a feeling of resentment against the N.H.S. that has been absent in the whole of its history until now. Conflict is, indeed, the new element that distinguishes this crisis from any of those in the past. Attitudes in the consultants' dispute have become more intransigent with arguments concentrating dangerously on semantics instead of principles. The Government seems determined unilaterally to redefine the gentlemen's agreement on part-time contracts. The consultants (see report on the C.C.H.M.S. meeting at p. 696) are equally determined to establish their interpretation of its workings before agreeing to reopen discussions. Indeed, the Hospital Consultants and Specialists Association are calling for more militant action by consultants.

Even within the medical profession consultants have traditionally been seen as remote from medical politics-so their present untypical militancy is surely indicative of their concern for the future. Management experts assert that repeated industrial action within any business concern is evidence of deeply felt resentments and needs radical measures to put the situation right. That diagnosis now applies to the nation's medical services.

\footnotetext{
1 Daily Telegraph, 11 March 1975.
2 British Medical fournal, 1974, 3, 124.

3 British Medical fournal, 1974, 4, 354.

4 The Times, 15 March 1975.
} 